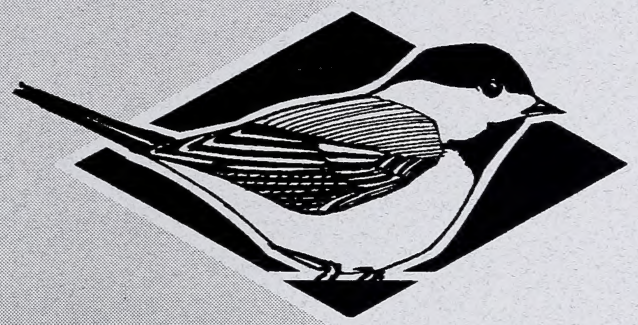

\title{
Status of the Sprague's Pipit (Anthus spragueii) in Alberta
}

\author{
David R. C. Prescott
}

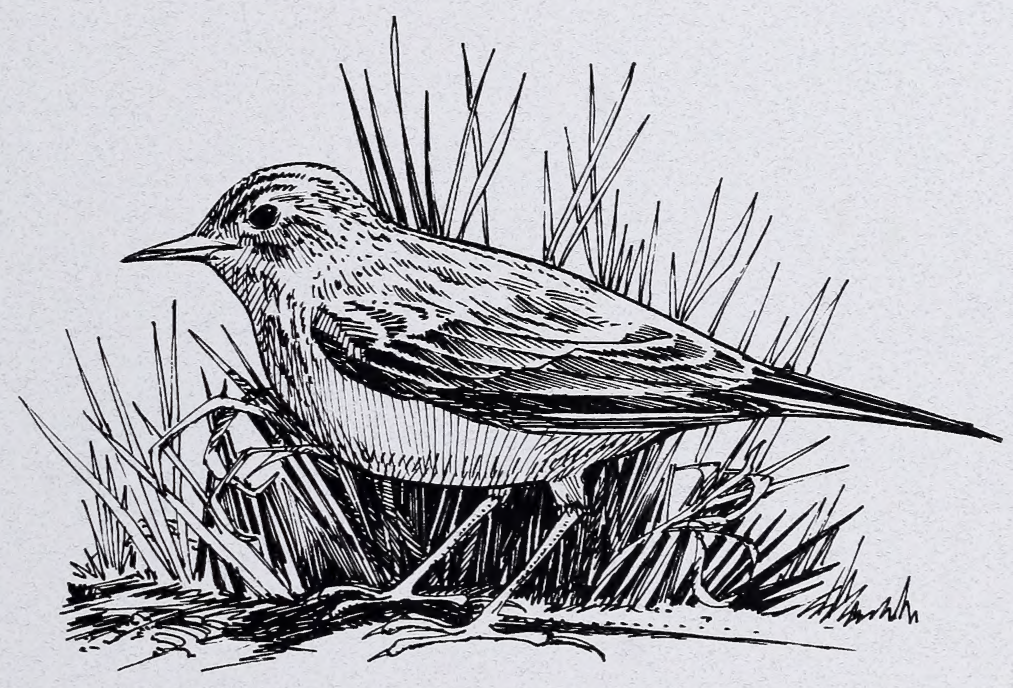

त्यो 
Digitized by the Internet Archive in 2015

https://archive.org/details/statusofspragues00pres 


\title{
Status of the Sprague's Pipit (Anthus spragueii) in Alberta
}

\author{
David R. C. Prescott
}

Alberta Wildlife Status Report No. 10

Published By:
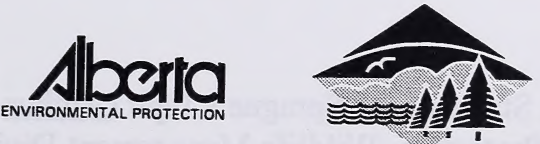
Series Editor: David R. C. Prescott Illustrations: Brian Huffman

For copies of this report, contact:

Information Centre - Publications Alberta Environmental Protection

Natural Resources Service

Main Floor, Bramalea Building 9920 - 108 Street

Edmonton, Alberta, Canada T5K 2M4

Telephone: (403) 422-2079

\section{OR}

Communications Division

Alberta Environmental Protection

\#100, 3115 - 12 Street NE

Calgary, Alberta, Canada T2E 7J2

Telephone: (403) 297-3362

This publication may be cited as:

Prescott, D. R. C. 1997. Status of the Sprague's Pipit (Anthus spragueii) in Alberta. Alberta Environmental Protection, Wildlife Management Division, Wildlife Status Report No. 10, Edmonton, AB. 14 pp. 


\section{PREFACE}

Every five years, the Wildlife Management Division of Alberta Natural Resources Service reviews the status of wildlife species in Alberta. These overviews, which have been conducted in 1991 and 1996, assign individual species to "color" lists which reflect the perceived level of risk to populations which occur in the province. Such designations are determined from extensive consultations with professional and amateur biologists, and from a variety of readily-available sources of population data. A primary objective of these reviews is to identify species which may be considered for more detailed status determinations.

The Alberta Wildlife Status Report Series is an extension of the 1996 Status of Alberta Wildlife review process, and provides comprehensive current summaries of the biological status of selected wildlife species in Alberta. Priority is given to species that are potentially at risk in the province (Red or Blue listed), that are of uncertain status (Status Undetermined), or which are considered to be at risk at a national level by the Committee on the Status of Endangered Wildlife in Canada (COSEWIC).

Reports in this series are published and distributed by the Wildlife Management Division of Alberta Environmental Protection, and are intended to provide detailed and up-to-date information which will be useful to resource professionals for managing populations of species and their habitats in the province. The reports are also designed to provide current information which will assist the proposed Alberta Endangered Species Conservation Committee to identify species that may be formally designated as endangered or threatened under the Alberta Wildlife Act. To achieve these goals, the reports have been authored and/or reviewed by individuals with unique local expertise in the biology and management of each species. 


\section{EXECUTIVE SUMMARY}

In response to declining population size and a paucity of information on its biology and management, the Sprague's Pipit (Anthus spragueii) is currently included on the "Blue List" of species that may be at risk in Alberta. This review summarizes information on the Sprague's Pipit, as a step in updating the status of this species in the province.

Sprague's Pipits breed on the Canadian prairies and northern Great Plains, and winter in the southern United States and northern Mexico. Throughout its range, the Sprague's Pipit shows a marked preference for native grasslands, with cover of intermediate height and density. In most regions, the highest abundances are attained on ungrazed to moderatelygrazed grasslands. The species may avoid areas with excessive accumulation of litter, and dense, matted vegetation.

Populations have declined rapidly in most areas of the breeding range over the past 30 years, with Canadian and continental populations being reduced by 7.3 and $4.6 \%$ per year, respectively. Declines in Alberta, where the species reaches its highest continental abundance, have been more rapid (10.0\% per year) over the same period. Population declines are probably linked to a loss of native grasslands, although cattle grazing, haying, and a reduction of fire frequencies in prairie regions may also be important factors.

The Sprague's Pipit remains a relatively common songbird on native grasslands within its provincial range. However, the continuing loss of breeding habitat and rapidly declining populations in Alberta, and in most parts of its range, are cause for concern. The development of appropriate management strategies to halt population declines will require continued research into the ecology of this species, and a better understanding of its responses to potential limiting factors. 


\section{ACKNOWLEDGEMENTS}

I thank Brenda Dale (Canadian Wildlife Service), Glenn Sutter (University of Regina), and Steven Davis (Saskatchewan Wetland Conservation Corporation) for supplying published and unpublished information used in this report, and for reviewing a preliminary draft of the document. I also thank Earl Wiltse (Saskatchewan Energy and Resource Management), Bob Jones (Manitoba Department of Natural Resources), Doug Johnson (U. S. Geological Survey, Biological Resources Division), Dave Obe and Doug Backlund (South Dakota Dept. of Game, Fish and Parks) and Kathy Duttenhefner (North Dakota Natural Heritage Inventory) for providing information on the status of Sprague's Pipit in their jurisdictions, and Jane Horb for producing the maps.

The project was funded by the Wildlife Management Enhancement Fund of Alberta Natural Resources Service, and the Alberta Conservation Association. 


\section{TABLE OF CONTENTS}

PREFACE iii

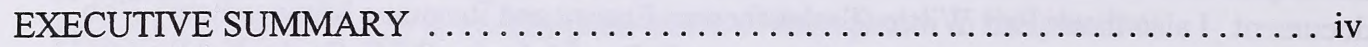

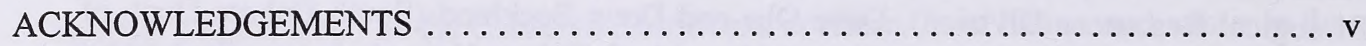

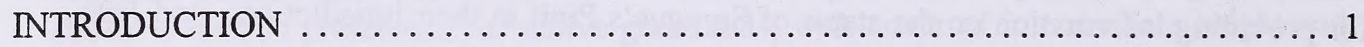

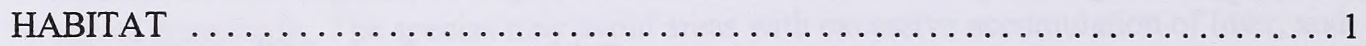

CONSERVATION BIOLOGY $\ldots \ldots \ldots \ldots \ldots \ldots \ldots \ldots \ldots \ldots \ldots \ldots \ldots \ldots \ldots \ldots \ldots \ldots \ldots \ldots \ldots$

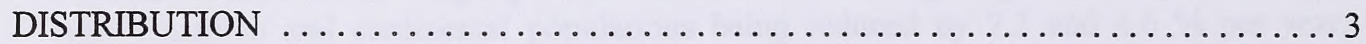

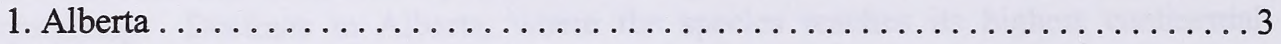

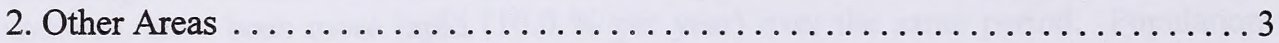

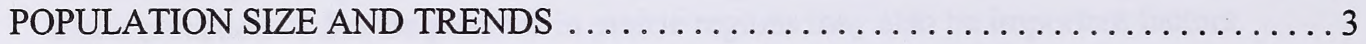

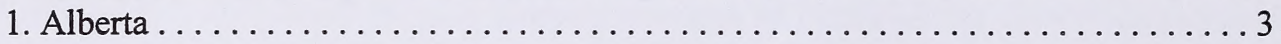

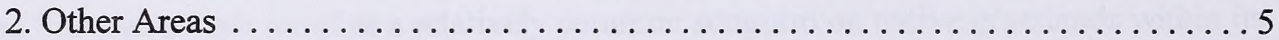

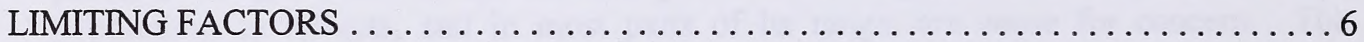

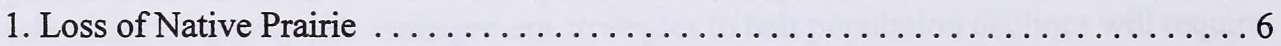

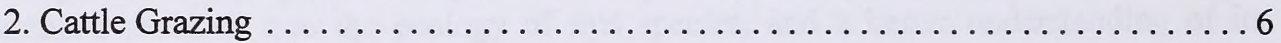

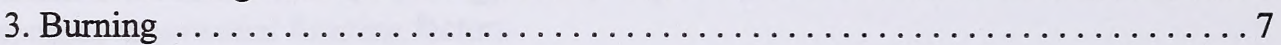

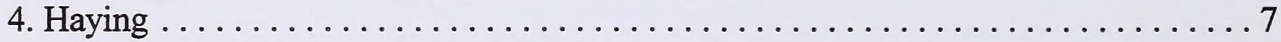

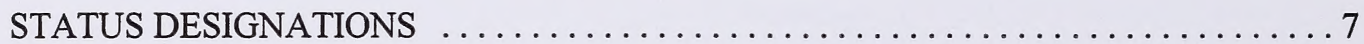

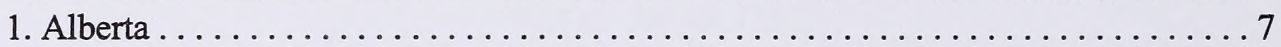

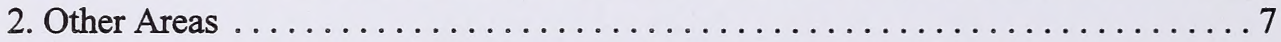

RECENT MANAGEMENT IN ALBERTA $\ldots \ldots \ldots \ldots \ldots \ldots \ldots \ldots \ldots \ldots$

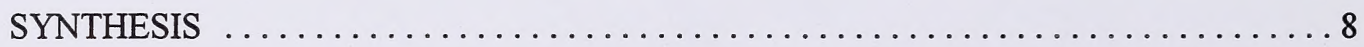

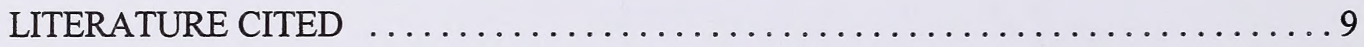

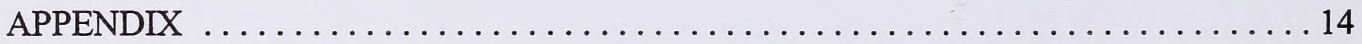




\section{INTRODUCTION}

The Sprague's Pipit (Anthus spragueii) is a small ( 15 to $17 \mathrm{~cm}, 23$ to $25 \mathrm{~g}$ ), groundnesting songbird that is endemic to the Canadian prairies and northern Great Plains of the United States. Although the species is relatively common in suitable habitat over much of its range, populations have been declining in many areas. This, coupled with a relative lack of information on the biology and management of this species, has led to the inclusion of the Sprague's Pipit on the "Blue List*" of species that may be at risk in Alberta (Alberta Wildlife Management Division 1996).

This report synthesizes available information on the biology and status of the Sprague's Pipit, with emphasis on breeding populations in Alberta.

\section{HABITAT}

Accounts from throughout the range of the Sprague's Pipit have emphasized the close association of this species with native prairie, and a strong aversion to introduced grasses and cultivated land (Berkey et al. 1993, Dale 1990, 1991, 1992, 1993a, Davis and Duncan in press, Davis et al. 1996a, De Smet and Conrad 1991, Kantrud and Koligoski 1982, Madden 1996, Owens and Myres 1973, Prescott and Wagner 1996, Wilson and Belcher 1989). In southern Alberta, both Owens and Myres (1973) and Prescott and Wagner (1996) observed that the species was 15 times more common on surveys in native fescue or mixed-grass prairie than in agricultural areas or tame (seeded) pastures. Prescott and Bilyk (1996) found Sprague's Pipits on $44.4 \%$ and $63.0 \%$ of surveys in fescue and mixed grasslands, respectively, but found none in tame hayfields, tame pasture, or cropland in 1995 and 1996. In Alberta's aspen parkland, inventories of 16 upland habitat types found Sprague's Pipits only in idle native grasslands ( $25 \%$ of census areas, Prescott et al. 1995). A more detailed inventory of rangelands in this biome revealed Sprague's Pipits in $6.8 \%$ of native rangelands, versus $1.1 \%$ of tame pastures (Prescott and Murphy 1996). The species is absent from dense nesting cover planted for waterfowl habitat in this area (Prescott and Murphy in press), and other areas of the Canadian prairies and northern Great Plains (Dale 1993a, Hartley 1994, Johnson and Schwartz 1993, Jones 1994).

On native range, the Sprague's Pipit is often one of the most common grassland songbirds (Dale 1984, Owens and Myres 1973), with reported densities of 1.3 to 46 pairs/100 ha (Dale 1984, De Smet and Conrad 1991, Pylypec 1991, Maher 1979). The species apparently prefers areas that are intermediate in terms of vegetation height and litter depth in both prairie and parkland regions of the Canadian prairies (Dale 1992, Prescott and Murphy 1996, Sutter 1996), and tends to avoid areas with excessive shrub cover (Dale 1983, Davis et al. 1996b, Madden 1996). The highest abundances are usually attained on ungrazed to moderately-grazed native range (Dale 1984, Davis et al. 1996b, Faanes 1983, Maher 1973, Owens and Myres 1973, Wershler et al. 1991).

\section{CONSERVATION BIOLOGY}

The earliest date for arrival of Sprague's Pipits on the breeding grounds in Alberta is 22 April (Sadler and Myres 1976, Pinel et al. 1993), although Farley (1932) reported that the mean arrival date for Camrose was 12 May. There

* See Appendix for definitions of selected status designations 
is virtually no information on territorial establishment and defence. Unlike most other grassland birds, Sprague's Pipits rarely sing from the ground. Rather, males deliver the song during extended display flights that are high above the nesting habitat (Bent 1950, McConnell et al. 1993). When on the ground, both males and females are difficult to approach, and flush far ahead of the observer or run through the grass to avoid detection. The elusive nature of the Sprague's Pipit makes close observations of behavior difficult to collect, and the breeding biology of this species is poorly understood.

Observations of nesting are also scant, because the nest is often placed in a depression below ground level, is wellconcealed with a grass roof, and is difficult to locate (Bent 1950, Harris 1933, Sutter in press). Sutter (1996) reported that Sprague's Pipits prefer to nest in dense, grassy, and relatively tall vegetation with low density of forbs and little bare ground. Selection of these areas probably maximizes protection against predation and heat stress.

Nest building has been observed during the second week of May in Manitoba (Davis 1994). Maher (1973) reported eggs as early as 15 May and as late as the end of July in Saskatchewan (Maher 1973), with the median date being 9 June. Four- or five-egg clutches are typical, but clutches of six eggs have been reported (Bent 1950, Maher 1973). Dale (unpubl. data), Maher (1973) and Sutter (1996) reported mean clutch sizes of 4.8 $(n=7), 4.45 \quad(n=49)$ and $4.6(n=51)$ eggs, respectively. Some females raise two broods in a season (Berkey et al. 1993, Harris 1933, Maher 1973, Sutter et al. in press), starting the second nest as much as 21 days after successful fledging of the first (G. Sutter, pers. comm.). The frequency of double broods is not known, but is probably low (G. Sutter, pers. comm.). Incubation, conducted exclusively by the female, lasts from 10 to 11 days (Bent 1950, Maher 1973, Sutter 1996, S. Davis, pers. comm.). The female is also primarily, if not exclusively, responsible for tending to the chicks (G. Sutter, pers. comm.). Maher (1973) reported 7 July as the mean date of nest departure in Saskatchewan. Harris (1933) and Dale (unpubl. data) reported young in the nest as late as 18 and 31 August in Manitoba and Saskatchewan, respectively.

Maher (1973) reported that the frequency of successful nests in Saskatchewan ranged from 22 to $33 \%$, with $53 \%$ and $42 \%$ of nests surviving the incubation and nestling period, respectively. Predation accounted for 64 to $69 \%$ of all nest losses. Davis and Sealy (in press) reported that nest success in Manitoba was $14 \%$, with $53 \%$ of nests being depredated. The incidence of parasitism by Brown-headed Cowbirds appears to be low. Maher (1973) observed no incidences in 49 nests, whereas De Smet and Conrad (1991) and Davis and Sealy (in press) in Manitoba found parasitism on one of six (17\%), and three of $17(18 \%)$ nests, respectively. Parasitism was reported on two of 23 (8.7\%) Prairie Nest Record Scheme cards, but on none of four cards received from Alberta (B. Dale, pers. comm.).

The Sprague's Pipit is almost entirely insectivorous (Grzybowski 1982, Maher 1979), with seeds constituting less than three percent of the adult diet during the breeding season (Maher 1974). Insect foods vary seasonally, with beetles comprising over $40 \%$ of the adult diet in May, and grasshoppers increasing from four percent in May to $91 \%$ in September (Maher 1974). Grasshoppers also constitute most of the nestling diet (55\% in July, $87 \%$ in August), with most of the 
remainder being lepidopteran larvae, leaf hoppers, spiders and hymenopterans (Harris 1933, Maher 1974, 1979).

Sprague's Pipits undergo a pre-basic moult (partial in juveniles, complete in adults) from late July through August (Maher 1973, Pyle et al. 1987), and depart for the wintering grounds in mid-September. Sadler and Myres (1976) report the latest sighting for Alberta on 19 September, but Maher (1973) and Dale (pers. comm.) recorded Sprague's Pipits in Saskatchewan as late as the first week of October. The species migrates through the Great Plains to the wintering grounds in the southern United States and northern Mexico (American Ornithologists' Union 1983). Wintering habitat in the southern United States has been described as heavily-grazed grasslands (Grzybowski 1982), but in northern Mexico, Sprague's Pipits occur in areas with higher than average coverage of tall forbs and grass, little shrub cover, and average values of litter (Bradley and Leukering 1996).

\section{DISTRIBUTION}

1. Alberta. - Salt and Salt (1976) reported that the breeding range of the Sprague's Pipit extends from southern Alberta through the aspen parkland to Athabasca and the Peace district, and west to the foothills of the Rocky Mountains. The species was not reported from the Peace parkland during the Alberta Bird Atlas project (Semenchuk 1992), suggesting a withdrawl from this area in the late 1970s and early 1980s. The species was relatively uncommon in the aspen parkland during the Atlas project, with records being obtained from approximately $11 \%$ of surveyed squares. The sparse distribution within this natural region appears similar to that described 60 years ago by Farley (1932), who observed the Sprague's Pipit to be an "uncommon and locally distributed summer resident" in the central aspen parkland. Sprague's Pipits are broadly distributed across the prairie region, with breeding evidence from approximately $21 \%$ of surveyed Atlas squares (Semenchuk 1992).

2. Other Areas. - Alberta lies at the northwestern corner of the range of the Sprague's Pipit. In Canada, this range extends through central Saskatchewan as far north as Prince Albert and Shoal Lake on the fringe of the boreal forest (Smith 1996), through westcentral and southern Manitoba south to southern Montana, south-central South Dakota, and northwestern Minnesota (American Ornithologists' Union 1983, Figure 1). A single breeding record from the Cariboo region of south-central British Columbia may represent a recent range expansion to that area (McConnell et al. 1993).

Sprague's Pipits winter from south-central and southeastern Arizona, southern New Mexico, central and eastern Texas, northwestern Mississippi, and southern Louisiana south through Mexico as far as Michoacan, Puebla and Veracruz (American Ornithologists' Union 1983). Christmas Bird Counts in the United States show the highest densities of birds in extreme southeastern Texas (Root 1988). Grzybowski (1982) also found the highest densities in this area. Bradley and Leukering (1996) encountered Sprague's Pipits on $11.2 \%$ of survey points along a 1200 $\mathrm{km}$ route through northern Mexico.

\section{POPULATION SIZE AND TRENDS}

1. Alberta. - There are no estimates of the population size of Sprague's Pipits in Alberta. The species is one of the most common grassland songbirds in many areas of native grassland, and according to Breeding Bird 


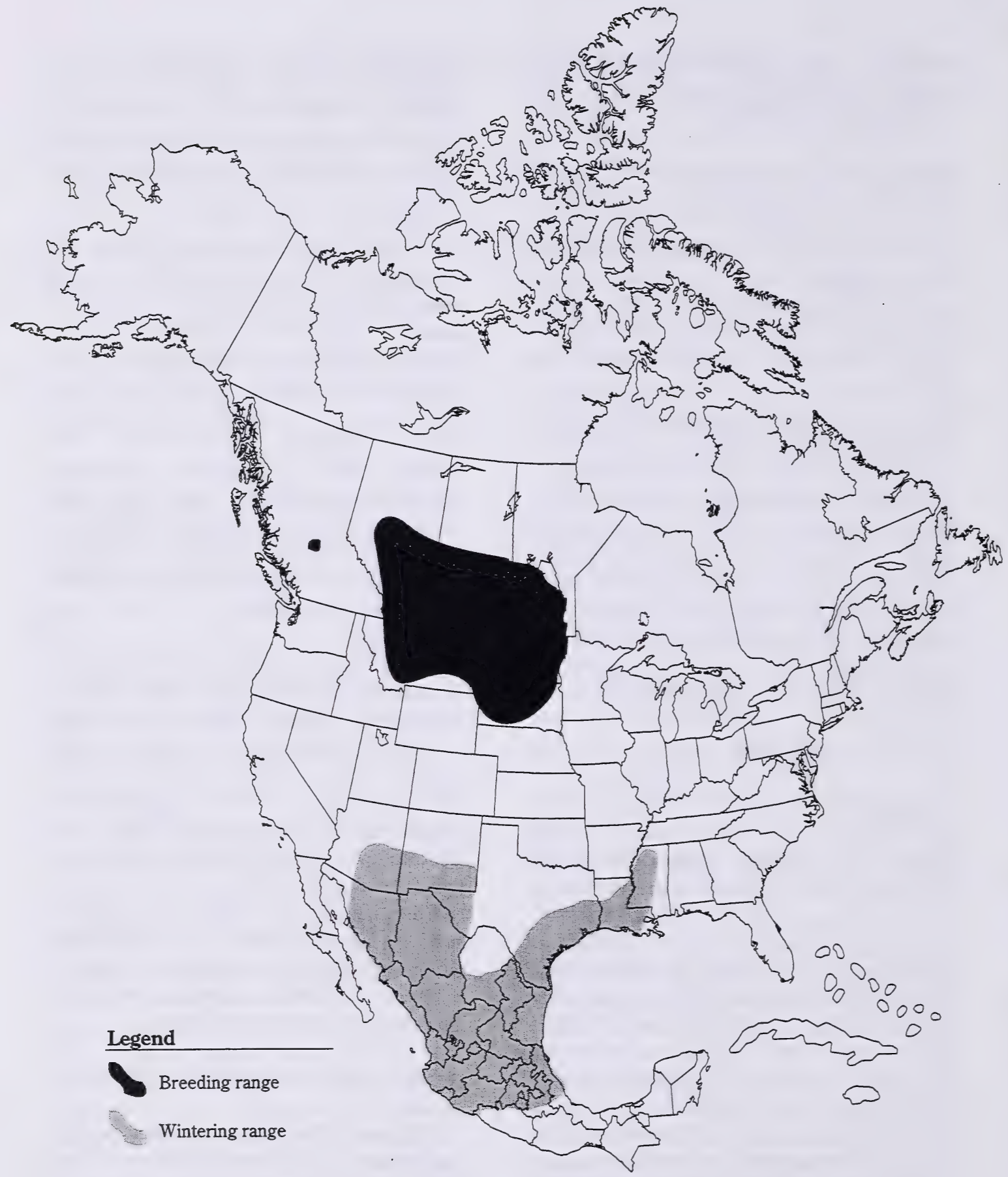

Figure 1. Breeding and wintering ranges of the Sprague's Pipit (modified from American Ornithologists' Union 1983). 
Survey (BBS) data, reaches its highest continental abundance in southeastern parts of the province (Sauer et al. 1996). The Sprague's Pipit was the third most abundant species in fescue grasslands near Handhills Lake (Owens and Myres 1973), and fifth most abundant in the same habitat type across the southern part of the prairie (Prescott and Bilyk 1996). In native mixed-grass prairie, the Sprague's Pipit was the seventh most abundant species in southern Alberta as a whole (Prescott and Bilyk 1996) and near Brooks (Prescott and Wagner 1996), and the fourth most frequently-encountered species on Canadian Forces Bases Suffield (B. Dale, unpubl. data). Sprague's Pipits ranked seventh in abundance on idle native grasslands in the aspen parkland (Prescott et al. 1995).

Although the population of Sprague's Pipits in Alberta likely numbers in the tens or hundreds of thousands, the species is declining rapidly in this province. Breeding Bird Survey trend data (Figure 2) indicate that populations declined at a statistically significant $10.0 \%$ per year between 1966 and 1995. This decline was particularly marked between 1980 and $1995(10.3 \%)$, with the decrease between 1966 and 1979 being a nonsignificant $6.8 \%$ per year (Sauer et al. 1996).

Breeding Bird Survey data probably provide a reasonable estimate of population trends in this species, but recent information suggests that Sprague's Pipits may avoid areas adjacent to roads (G. Sutter, unpubl. data). Surveys, such as the BBS, which are conducted along roads may therefore underestimate the numerical abundance of Sprague's Pipits.

2. Other Areas. - There are no estimates of population size from other states or provinces within the range of the Sprague's Pipit. However, populations appear to be declining in all areas, with the exception of Montana, where statistically- nonsignificant increases of

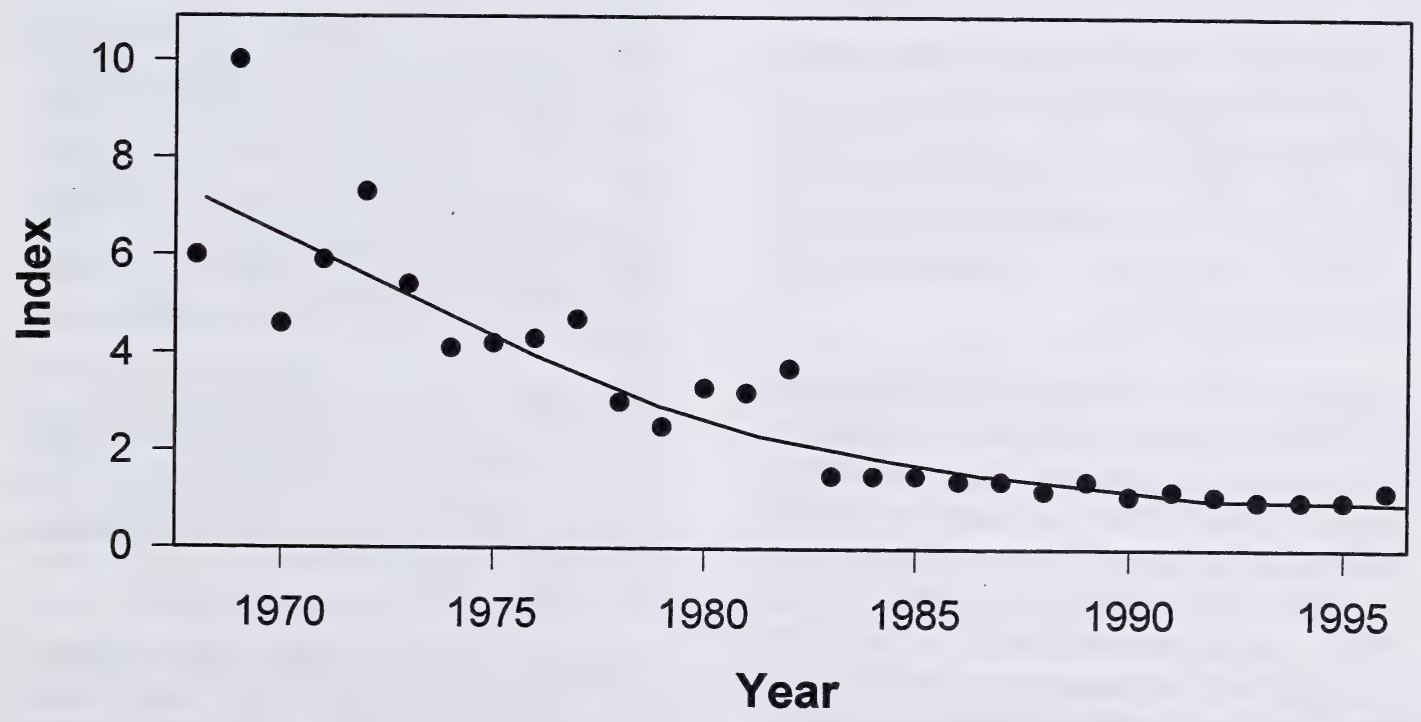

Figure 2. Index of population change of the Sprague's Pipit in Alberta, 1968-1996. Data are from the North American Breeding Bird Survey (modified from Sauer et al. 1996). 
$6.7 \%$ per year have been noted since 1966 (Sauer et al. 1996). In Saskatchewan, where the species currently ranks sixth or seventh among grassland birds in terms of abundance (Davis et al. 1996a, Skeel et al. 1995), populations have declined $4.8 \%$ per year since 1966 , and $7.9 \%$ per year since 1980 . Annual declines in North Dakota, which were $7.1 \%$ between 1966 and 1979, have stablilized during the past 15 years. In the last century, the species was one of the three most common grassland birds in that state (Coues 1878), but is now no higher than fifteenth in terms of abundance (Stewart and Kantrud 1972, Madden 1996). Overall estimates for Canada indicate a $7.3 \%$ annual decline since 1966, with continent-wide populations declining at $4.6 \%$ per year over the same period.

\section{LIMITING FACTORS}

A variety of factors may be responsible for the recent declines in continental and provincial populations of the Sprague's Pipit. Although climatic factors, such as drought (George et al. 1992), have been shown to decrease local populations of this species, the following discussion focuses on factors with an anthropogenic origin, which may be reversed through appropriate management or conservation activites.

1. Loss of Native Prairie - Native prairie and parkland has been extensively modified by agricultural activities over the past century. Approximately $75 \%$ of the Canadian prairies has been converted to agricultural use, including $68 \%$ in Alberta (Statistics Canada 1992). Losses or modifications in the aspen parkland have been even greater, with $80 \%$ of these habitats across the prairie now under agricultural use. In Alberta, only two to $10 \%$ of native parkland remains intact (Rowe 1987). The strong preference of Sprague's
Pipits for native grasslands, coupled with extensive loss or modification of these habitats across the Canadian prairies, is undoubtedly a major factor in the rapid decline of Sprague's Pipits in this area. Changes to habitat on the prairies may be most important to this decline, as breeding populations in this region are traditionally much larger than in the parkland.

2. Cattle Grazing. - Accounts from the Canadian prairies show that Sprague's Pipits prefer ungrazed to moderately-grazed native range (Dale 1983, Davis et al. 1996b, Maher 1973, 1979, Prescott and Wagner 1996, Prescott et al. 1995, Sutter 1996, Wershler et al. 1991), and will decline markedly under more intense grazing pressure (Karasiuk et al. 1977, Prescott and Wagner 1996). In other areas, such as North Dakota, where grassland productivity is higher (Madden 1996), Sprague's Pipits apparently prefers areas that are more heavily grazed (Kantrud 1981), and may avoid idled grasslands where vegetation has become matted (Berkey et al. 1993). Thus, light to moderate levels of grazing can produce suitable habitat is some regions (Bock et al. 1993). This may also be true in some parts of the Canadian prairies and parkland, where Sprague's Pipits prefer intermediate grass height and litter depths (Dale 1992, Prescott and and Murphy 1996, Sutter 1996). However, grasslands in southern Alberta tend to be more arid, and productivity of grass lower, than in other areas within the range of the Sprague's Pipit. In these areas, moderate levels of grazing are more likely to be detrimental to Sprague's Pipit populations (Bock et al. 1993).

Grazing not only modifies habitat suitability for grassland birds, but can reduce reproductive success through behavioral disturbance of nesting birds and trampling of nests by cattle (Kie and Loft 1990, Prescott et 
al. 1997). These factors have not specifically been investigated for Sprague's Pipits, but grazing of suitable habitat at critical phases of the nesting cycle undoubtedly affects recruitment in some areas.

3. Burning. - In the short term, fire has adverse effects on the abundance of Sprague's Pipits. Pylypec (1991) observed that density dropped from 0.3 to 0.14 pairs/ha one year after burning in Saskatchewan, but returned to pre-burn levels after three years. Other studies, however, have suggested that burning has longer-term benefits for Sprague's Pipits. Maher (1973) recorded large increases in Sprague's Pipit populations two years after a burn in Saskatchewan, and Madden (1996) reported that Sprague's Pipits reached their highest abundance between two and seven years after fire in North Dakota. Berkey et al. (1993) also reported that the Sprague's Pipit "responds well to burning" in North Dakota. Thus, fire may reduce habitat suitability for a brief period, but larger populations for several years thereafter should more than offset initial declines. Sprague's Pipits, and other grassland species that have evolved with frequent fires on the prairies, may therefore be limited by reduced fire frequencies that have accompanied human settlement, and which allow encroachment of shrubs and excessive accumulation of litter (Madden 1996).

4. Haying. - Haying, like grazing, alters habitat structure and can have major impacts on habitat for Sprague's Pipits. Furthermore, mowing during the nesting season can cause substantial reproductive failure in grassland birds, including Sprague's Pipits (Dale 1993b). However, there is only limited information on the responses of Sprague's Pipits to haying of native grasslands, probably because such land use, compared to grazing, is of relatively minor occurrence on the Great Plains.
Kantrud (1981) reported an absence of Sprague's Pipits on native grasslands hayed the previous season in North Dakota, whereas Owens and Myres (1973) found that Sprague's Pipits returned to fescue grasslands in southern Alberta late in the season following haying. It is unclear whether haying produces the longer-term benefits that are observed following burning, although Berkey et al. (1993) believed that Sprague's Pipits should "respond well" to occasional haying.

\section{STATUS DESIGNATIONS}

1. Alberta. - The Sprague's Pipit was considered to be a "status undetermined" species in the 1991 review of the status of Alberta wildlife (Alberta Fish and Wildlife 1991). The species was recently updated to the "Blue List" of species that current information suggests may be at risk in the province (Alberta Wildlife Management Division 1996). This designation was made on the basis of rapidly declining populations, and a lack of research into the biology and management of the species. The Sprague's Pipit is legally designated as a "non-game animal" under the Alberta Wildlife Act. Such species are provided with full protection, and cannot be killed, possessed, bought or sold without a permit.

2. Other Areas. - The Sprague's Pipit is not listed by the Committee on the Status of Endangered Wildlife in Canada (COSEWIC 1996), although a report on the status of this species in Canada is anticipated in the near future (S. Davis, pers. comm.). The Sprague's Pipit is not presently listed as a species of concern in either Saskatchewan (E. Wiltse, pers. comm.) or Manitoba (B. Jones, pers. comm.), but is included on the "Red List" of species considered to be candidates for designation as "threatened" or "endangered" 
in British Columbia (Harper et al. 1994, Hooper 1997). This designation was made on the basis of the restricted distribution and small population of the species in that province (Harper et al. 1994). However, the very small number of reports suggests that the species is of accidental or casual occurrence in British Columbia, and it may be removed from the provincial color list if no additional reports are received in the next few years (Hooper 1997).

The Sprague's Pipit is not listed as a species of concern in Montana (Reichel 1997) or North Dakota, but is considered to be "state rare" in the latter jurisdiction $(\mathrm{K}$. Duttenhefner, pers. comm.). Minnesota classifies Sprague's Pipit to be "endangered" (Anonymous 1996a), whereas the species is considered to be "imperiled because of rarity" in South Dakota (Anonymous 1996b).

\section{RECENT MANAGEMENT IN ALBERTA}

No specific management for the Sprague's Pipit has been reported in Alberta.

\section{SYNTHESIS}

The Sprague's Pipit is one of the most rapidly declining songbird species in Alberta, and in most other parts of its range in North America. More than most other species, the Sprague's Pipit is a native grassland specialist, and the decline in population size is likely linked to land-use changes on the prairie. Most important among these changes is the conversion of native grassland to tame pasture, hayfields and cropland.

The Sprague's Pipit reaches its highest breeding densities in Alberta (Sauer et al. 1996), and populations in the province are currently large. However, the decline in populations in this province is precipitous (10\% per year), and native prairie and parkland continues to be converted to other uses. This continuing habitat loss, and accompanying decline in population size, suggests that the decline of the Sprague's Pipit in the province will continue in the future.

Despite its relative abundance in suitable habitat, the Sprague's Pipit is a poorlyunderstood species (Lambeth and Lambeth 1988), and many aspects of its basic biology have only recently been described. Management to reverse population declines of Sprague's Pipits will require continued research into the basic biology of this species, and a more complete understanding of the impacts of potential limiting factors on population size and reproductive output. Given that the species is most common on native grasslands, investigations into the relationship between range-managment practices and habitat use by Sprague's Pipits may be a particularly fruitful avenue of research. Such studies may best be conducted in Alberta, where the largest populations on the continent currently occur. Once proper management to mitigate limiting factors is identified, it will be important to share this information with land owners and managers so that appropriate land-use practices can be implemented on a broad scale. 


\section{LITERATURE CITED}

Alberta Fish and Wildlife. 1985. A policy for the management of threatened and endangered wildlife in Alberta. Alberta Fish and Wildlife, Edmonton, AB. 34 pp.

Alberta Fish and Wildlife. 1991. The status of Alberta wildlife. Alberta Fish and Wildlife, Edmonton, AB. 49 pp.

Alberta Wildlife Management Division. 1996. The status of Alberta wildlife. Alberta Fish and Wildlife, Edmonton, $\mathrm{AB}$. $44 \mathrm{pp}$.

American Ornithologists' Union. 1983. Checklist of North American birds. A.O.U., Washington, DC. 877 pp.

Anonymous. 1996a. Minnesota Natural Heritage Program, anonymous FTP archive. URL: http//www.heritage.tnc.org/ $\mathrm{nhp} / \mathrm{us} / \mathrm{mn} / \mathrm{ftplist} . \mathrm{html}$.

Anonymous. 1996b. Animal species monitored by the South Dakota Natural Heritage Program. Unpubl. rept., South Dakota Dept. of Game, Fish and Parks, Pierre, SD. 7 pp.

Bent, A. C. 1950. Life histories of North American wagtails, shrikes, vireos, and their allies. U. S. Natl. Museum Bull. 197, Washington, DC. 411 pp.

Berkey, G., R. Crawford, S. Galipeau, D. Johnson, D. Lambeth, and R. Kreil. 1993. A review of wildlife management practices in North Dakota: effects on nongame bird populations and habitats. Unpubl. rept., U.S. Fish and Wildlife Service, Denver CO. $51 \mathrm{pp}$.
Bock, C. E., V. A. Saab, T. D. Rich, and D. S. Dobkin. 1993. Effects of livestock grazing on neotropical migratory landbirds in western North America. Pp. 296-309 in Status and management of neotropical migratory birds (D. M. Finch and P. W. Stangel, eds.). U. S. D. A. For. Serv. Gen. Tech. Rept. RM-229, Fort Collins, CO.

Bradley, J. S., and A. Leukering. 1996. Distribution and habitat associations of birds wintering in Mexican grasslands: 1996 pilot season report. Unpubl. rept., Colorado Bird Observatory, Brighton, CO. $11 \mathrm{pp}$.

COSEWIC. 1996. Canadian species at risk. Committee on the Status of Endangered Wildlife in Canada, Ottawa, ON. 18 pp.

Coues, E. 1878. Field notes on birds observed in Dakota and Montana along the 49th parallel during the seasons of 1873 and 1874. Bull. U. S. Geol. and Geogr. Survey Terr. 4:545-661.

Dale, B. C. 1983. Habitat relationships of seven species of passerine birds at Last Mountain Lake, Sakatchewan. Unpubl. M.Sc. thesis, Univ. Regina, Regina, SK. $119 \mathrm{pp}$.

Dale, B. C. 1984. Birds of grazed and ungrazed grasslands in Saskatchewan. Blue Jay 42:102-105.

Dale, B. 1990. The effect of haying on grassland passerines at Last Mountain Lake National Wildlife Area - 1989. Unpubl. rept., Canadian Wildlife Service, Saskatoon, SK. 25 pp.

Dale, B. C. 1991. North American Waterfowl Management Plan 
implementation program related to nongame bird studies within the Prairie Habitat Joint Venture area. Annual report 19901991. Unpubl. rept., Canadian Wildlife Service, Saskatoon, SK. 58 pp.

Dale, B. 1992. North American Waterfowl Management Plan implementation program related to non-game bird studies within the Prairie Habitat Joint Venture area. Annual report 1991-1992. Unpubl. rept., Canadian Wildlife Service, Saskatoon, SK. 66 pp.

Dale, B. 1993a. 1992 Saskatchewan nongame bird evaluation of North American Waterfowl Management Plan. DNC and short grass cover-1992. Unpubl. rept., Saskatchewan Wetland Conservation Corporation, Regina, SK. 23 pp.

Dale, B. 1993b. Productivity of endemic grassland passerines in haylands. Pp. 2732 in Proceedings of the third prairie conservation and endangered species workshop (G. L. Holroyd, H. L. Dickson, M. Regnier, and H. C. Smith, eds.). Prov. Mus. Alberta Nat. Hist. Occas. Pap. No. 19, Edmonton, AB. 384 pp.

Davis, S. K. 1994. Cowbird parasitism, predation, and host selection in fragmented grassland of southwestern Manitoba. Unpubl. M.Sc. thesis, Univ. Manitoba, Winnipeg, MB. 77 pp.

Davis, S. K., and D. C. Duncan. In Press. Grassland songbird occurrence in native and crested wheatgrass pastures of southern Saskatchewan. In Grassland birds of the western hemisphere (J. Herkert and P. Vickery, eds.). Studies in Avian Biology.
Davis, S. K., D. C. Duncan, and M. A. Skeel. 1996a. The Baird's Sparrow: status resolved. Blue Jay 54:185-191.

Davis, S. K., D. C. Duncan, D. A. Anstey, and M. A. Skeel. 1996b. Habitat selection of grassland songbirds in southern Saskatchewan. Unpubl. rept., Saskatchewan Wetland Conservation Corporation, Regina, SK. 31 pp.

Davis, S. K., and S. G. Sealy. In Press. Cowbird parasitism and nest predation in fragmented grasslands of southwestern Manitoba. In Ecology and management of cowbirds (T. Cook, S. K. Robinson, S. T. Rothstein, S. G. Sealy and J. N. M. Smith, eds.). Univ.Texas Press, Austin, TX.

De Smet, K. D., and M. P. Conrad. 1991. Management and research needs for Baird's Sparrows and other grassland species in Manitoba. Pp. 83-86 in Proceedings of the second endangered species and prairie conservation workshop (G. L. Holroyd, G. Burns, and H. C. Smith, eds.). Prov. Mus. Alberta Nat. Hist. Occas. Pap. No. 15, Edmonton, AB. 284 pp.

Faanes, C. A. 1983. Breeding birds of wooded draws in western North Dakota. Prairie Nat. 15:173-187.

Farley, F. L. 1932. Birds of the Battle River region. Institute of Applied Arts, Edmonton, AB. 62 pp.

George, T. L., A. C. Fowler, R. L. Knight, and L. C. McEwen. 1992. Impacts of a severe drought on grassland birds in western North Dakota. Ecol. Appl. 2:275-284. 
Grzybowski, J. A. 1982. Population structure of grassland bird communities during winter. Condor 84:137-152.

Harper, B., S. Cannings, D. Fraser, and W. T. Munro. 1994. Provincial lists of species at risk. Pp. 16-23 in Biodiversity in British Columbia (L. E. Harding and E. McCullum, eds.). Can. Wildl. Serv., Delta, BC.

Harris, R. D. 1933. Observations on a nest of Sprague's Pipit (Anthus spraguei). Can. Field-Natur. 47:91-95.

Hartley, M. J. 1994. Passerine abundance and productivity indices in grasslands managed for waterfowl nesting cover in Saskatchewan, Canada. Unpubl. M.Sc thesis, Louisiana State Univ., Baton Rouge, LA. $42 \mathrm{pp}$.

Hooper, T. D. 1997. Status of the Sprague's Pipit in British Columbia. B. C. Environment, Wildlife Working Rept. No. WR-88, Victoria, BC. 7 pp.

Johnson, D. H., and M. D. Schwartz. 1993. The Conservation Reserve Program: habitat for grassland birds. Great Plains Research 3:273-295.

Jones, R. E. 1994. Nonwaterfowl evaluation of Manitoba's North American Waterfowl Management program. Unpubl. rept., Manitoba Dept. Natur. Res., Wildl. Branch, Winnipeg, MB. 15 pp.

Kantrud, H. A. 1981. Grazing intensity effects on the breeding avifauna of North Dakota native grasslands. Can. FieldNatur. 95:404-417
Kantrud, H. A., and R. L. Kologiski. 1982. Effects of soils and grazing on breeding birds of uncultivated upland grasslands of the northern Great Plains. U. S. Dept. Interior, Fish and Wildl. Serv. Wild. Res. Rept. 15, Washington, DC. 33 pp.

Karasiuk, D., H. Vriend, J. Stelfox, A. Smith, and J. McGillis. 1977. Avifauna. Pp. E35-E59 in Effects of livestock grazing on mixed prairie range and wildlife within PFRA pastures, Suffield Military Reserve (J. Stelfox, ed.). Unpubl. rept., Canadian Wildlife Service, Edmonton, AB.

Kie, J. G., and E. R. Loft. 1990. Using livestock to manage wildlife habitat: some examples from California annual grassland and wet meadow communities. Pp. 7-24 in Can wildlife be used as a tool to enhance wildlife habitat? (K. E. Severson, ed.). U.S.D.A. For. Serv. Gen. Tech. Rept. RM194, Fort Collins, CO. 123 pp.

Lambeth, D. O., and S. O. Lambeth. 1988. Sprague's Pipits nest in Polk County. Loon 60:104-108.

Madden, E. M. 1996. Passerine communities and bird-habitat relationships on prescribeburned, mixed-grass prairie in North Dakota. Unpubl. M.Sc. thesis, Montana State Univ., Bozeman, MT. 153 pp.

Maher, W. J. 1973. Matador project. Birds: I. Population dynamics. Canadian Committee for the International Biological Programme Tech. Rept. No. 34, Saskatoon, SK. 50 pp.

Maher, W. J. 1974. Matador project. Birds: III. Food habits. Canadian Committee for the International Biological Programme 
Tech. Rept. No. 52, Saskatoon, SK. 107 pp.

Maher, W. J. 1979. Nestling diets of prairie passerine birds at Matador, Saskatchewan, Canada. Ibis 121: 437-452.

McConnell, S. D., R. Van den Driessche, T. D. Hooper, G. L. Roberts, and A. Roberts. 1993. First occurrence and breeding of Sprague's Pipit, Anthus spragueii, for British Columbia. Can. Field-Natur. 107:222-223.

National Research Council. 1995. Science and the Endangered Species Act. National Academy Press, Washington, DC. 271 pp.

Owens, R. A., and M. T. Myres. 1973. Effects of agriculture upon populations of native passerine birds of an Alberta fescue grassland. Can. J. Zool. 51:697-713.

Pinel, H. W., W. W. Smith, and C. R. Wershler. 1993. Alberta birds, 1971-1980. Vol. 2. Passerines. Prov. Mus. Alberta, Nat. Hist. Occas. Paper No. 13. Edmonton, AB. 243 pp.

Prescott, D. R. C., and J. Bilyk. 1996. Avian communities and NAWMP habitat priorities in the southern prairie biome of Alberta. Alberta NAWMP Centre and Land Stewardship Centre of Canada. NAWMP-026. Edmonton, AB. 43 pp.

Prescott, D. R. C., B. C. Dale, R. Dickson, and M. Piorecky. 1997. Effects of timing and intensity of grazing on nest success of upland-nesting birds on the University Ranch, 1996. Unpubl. rept., Land Stewardship Centre of Canada and Canadian Wildlife Service, Edmonton, AB. $21 \mathrm{pp}$.
Prescott, D. R. C., and A. J. Murphy. In Press. Bird populations of seeded grasslands in the aspen parkland of Alberta. In Grassland birds of the western hemisphere (J. Herkert and P. Vickery, eds.). Studies in Avian Biology.

Prescott, D. R. C., and A. J. Murphy. 1996. Habitat associations of grassland birds on native and tame pastures in the aspen parkland of Alberta. Alberta NAWMP Centre. NAWMP-021. Edmonton, AB. $36 \mathrm{pp}$.

Prescott, D. R. C., A. J. Murphy, and E. Ewaschuk. 1995. An avian community approach to determining the biodiversity value of NAWMP habitats in the aspen parkland of Alberta. Alberta NAWMP Centre. NAWMP-012. Edmonton, AB. $58 \mathrm{pp}$.

Prescott, D. R. C., and G. M. Wagner. 1996. Avian responses to implementation of a complementary/rotational grazing system by the North American Waterfowl Management Plan in southern Alberta: the Medicine Wheel project. Alberta NAWMP Centre. NAWMP-018. Edmonton, AB. $24 \mathrm{pp}$.

Pyle, P., S. N. G. Howell, R. P. Yunick, and D. F. DeSante. 1987. Identification guide to North American passerines. Slate Creek Press, Bolinas, CA. 278 pp.

Pylypec, B. 1991. Impacts of fire and bird populations in a fescue prairie. Can. FieldNatur. 105:346-349.

Reichel, J. D. 1997. Montana species of special concern. Unpubl. rept., Montana Natural Heritage Program, Helena, MT. 9 pp. 
Root, T. 1988. Atlas of wintering North American birds. Univ. Chicago Press, Chicago, IL. 312 pp.

Rowe, J. S. 1987. Status of the aspen parkland in the prairie provinces. Pp. 2734 in Endangered species in the prairie provinces (G. L. Holroyd, P. H. R. Stepney, G. C. Trottier, W. B. McGillivray, D. M. Ealey, and K. E. Eberhart, eds.). Prov. Mus. Alberta Nat. Hist. Occas. Paper No. 9. Edmonton, AB. 367 pp.

Sadler, T. S., and M. T. Myres. 1976. Alberta birds, 1961-1970, with particular reference to migration. Prov. Mus. Alberta Nat. Hist. Occas. Paper No. 1. Edmonton, AB. 304 pp.

Salt, W. R, and J. R. Salt. 1976. The birds of Alberta. Hurtig Publishers, Edmonton, AB. $498 \mathrm{pp}$.

Sauer, J. R., S. Schwartz, B. G. Peterjohn, and J. E. Hines. 1996. The North American Breeding Bird Survey home page. Version 95.1. Patuxent Wildlife Research Center, Laurel, MD. URL: http://www.mbr. nbs.gov/bbs

Semenchuk, G. P. (ed.). 1992. The atlas of breeding birds of Alberta. Federation of Alberta Naturalists, Edmonton, AB. 391 pp.

Skeel, M. A., D. C. Duncan, and S. K. Davis. 1995. Abundance and distribution of Baird's Sparrows in Saskatchewan in 1994. Unpubl. rept., Saskatchewan Wetland Conservation Corporation, Regina, SK. 13 pp. + appendices.
Smith, A. R. 1996. Atlas of Saskatchewan birds. Sask. Nat. Hist. Soc. Spec. Publ. No. 22, Regina, SK.

Statistics Canada. 1992. 1991 census of agriculture. Statistics Canada, Ottawa, ON.

Stewart, R. E., and H. A. Kantrud. 1972. Population estimates of breeding birds in North Dakota. Auk 89:766-788.

Sutter, G. C. 1996. Habitat selection and prairie drought in relation to grassland bird community structure and the nesting ecology of Sprague's Pipit (Anthus spragueii). Unpubl. Ph.D. thesis, Univ. Regina, Regina, SK. 144 pp.

Sutter, G. C., D. J. Sawatzky, D. M. Cooper, and R. M. Brigham. In Press. Renesting intervals in Sprague's Pipit, Anthus spragueii. Canadian Field-Naturalist.

Wershler, C., W. W. Smith, and C. Wallis. 1991. Status of the Baird's Sparrow in Alberta - 1987/1988 update with notes on other grassland sparrows and Sprague's Pipit. Pp. 87-92 in Proceedings of the second endangered species and prairie conservation workshop (G. L. Holroyd, G. Burns, and H. C. Smith, eds.). Prov. Mus. Alberta Nat. Hist. Occas. Paper No. 15, Edmonton, AB. 284 pp.

Wilson, S. D., and J. W. Belcher. 1989. Plant and bird communities of native prairie and introduced Eurasian vegetation in Manitoba, Canada. Conserv. Biol. 3:39-44. 


\section{A. Status of Alberta Wildlife color lists (after Alberta Wildlife Management Division 1996)}

\begin{tabular}{|l|l|}
\hline Red & $\begin{array}{l}\text { Current knowledge suggests that these species are at risk. These species have declined, or are in } \\
\text { immediate danger of declining, to nonviable population size }\end{array}$ \\
\hline Blue & $\begin{array}{l}\text { Current knowledge suggests that these species mav be at risk. These species have undergone } \\
\text { non-cyclical declines in population or habitat, or reductions in provincial distribution }\end{array}$ \\
\hline Yellow & $\begin{array}{l}\text { Species that are not currently at risk, but may require special management to address concerns } \\
\text { related to naturally low populations, limited provincial distributions, or demographic/life history } \\
\text { features that make them vulnerable to human-related changes in the environment }\end{array}$ \\
\hline Green & Species not considered to be at risk. Populations are stable and key habitats are generally secure \\
\hline Undetermined & Species not known to be at risk, but insufficient information is available to determine status \\
\hline
\end{tabular}

\section{B. Alberta Wildlife Act}

Species designated as "endangered" under the Alberta Wildlife Act include those defined as "endangered" or "threatened" by A Policy for the Management of Threatened Wildlife in Alberta (Alberta Fish and Wildlife 1985):

\begin{tabular}{|l|l|}
\hline Endangered & A species whose present existence in Alberta is in danger of extinction within the next decade \\
\hline Threatened & $\begin{array}{l}\text { A species that is likely to become endangered if the factors causing its vulnerability are not } \\
\text { reversed }\end{array}$ \\
\hline
\end{tabular}

\section{Committee on the Status of Endangered Wildlife in Canada (after COSEWIC 1996)}

\begin{tabular}{|l|l|}
\hline Extirpated & A species no longer existing in the wild in Canada, but occurring elsewhere \\
\hline Endangered & A species facing imminent extirpation or extinction \\
\hline Threatened & A species likely to become endangered if limiting factors are not reversed \\
\hline Vulnerable & $\begin{array}{l}\text { A species of special concern because of characteristics that make it particularly sensitive to } \\
\text { human activities or natural events }\end{array}$ \\
\hline Not at Risk & A species that has been evaluated and found to be not at risk \\
\hline Indeterminate & A species for which there is insufficient scientific information to support status designation \\
\hline
\end{tabular}

\section{United States Endangered Species Act (after National Research Council 1995)}

\begin{tabular}{|l|l|}
\hline Endangered & Any species which is in danger of extinction throughout all or a significant portion of its range \\
\hline Threatened & $\begin{array}{l}\text { Any species which is likely to become an endangered species within the foreseeable future } \\
\text { throughout all or a significant portion of its range }\end{array}$ \\
\hline
\end{tabular}




\section{List of Titles In This Series}

(as of September 1997)

No. 1 Status of the Piping Plover (Charadrius melodus) in Alberta, by David R. C. Prescott. 19 pp.

No. 2 Status of the Wolverine (Gulo gulo) in Alberta, by Stephen Petersen. $17 \mathrm{pp}$.

No. 3 Status of the Northern Long-eared Bat (Myotis septentrionalis) in Alberta, by M. Carolina Caceres and M. J. Pybus. 19 pp.

No. 4 Status of the Ord's Kangaroo Rat (Dipodomys ordii) in Alberta, by David L. Gummer. 16 pp.

No. 5 Status of the Eastern Short-horned Lizard (Phrynosoma douglassii brevirostre) in Alberta, by Janice D. James, Anthony P. Russell and G. Lawrence Powell. 20 pp.

No. 6 Status of the Prairie Rattlesnake (Crotalus viridis viridis) in Alberta, by Sheri M. Watson and Anthony P. Russell. 26 pp.

No. 7 Status of the Swift Fox (Vulpes velox) in Alberta, by Susan E. Cotterill. 17pp.

No. 8 Status of the Peregrine Falcon (Falco peregrinus anatum) in Alberta, by Petra Rowell and David P. Stepnisky. In Preparation.

No. 9 Status of the Northern Leopard Frog (Rana pipiens) in Alberta, by Greg Wagner. In Preparation.

No. 10 Status of the Sprague's Pipit (Anthus spragueii) in Alberta, by David R. C. Prescott. 14 pp.

No. 11 Status of the Burrowing Owl (Speotyto cunicularia hypugaea) in Alberta, by Troy I. Wellicome. 21 pp. 


\section{NOTES}




\section{NOTES}




\section{NOTES}


National Library of Canada Bibliothèque nationale du Canada

3 3286513567012 